\section{After the slaughter: reconstructing Mozambique and Rwanda}

\section{J. Paul Dunne}

Introduction

$\mathrm{O}$ ne of the major concerns facing the developing world is how to deal with the aftermath of conflict. Conflicts can be immensely damaging to economies, but also leave scars on societies that go much deeper. The variety of forms conflict can take makes it difficult to draw general conclusions from the limited available literature in this field and makes it important to consider the experiences of particular countries. Here are considered the experiences of two countries that have seen rather different but terrible conflict in recent times: Mozambique, which has been recovering from a brutal civil war made worse by the involvement of external actors, and Rwanda, which has been recovering from horrific genocide. Drawing on work reported elsewhere, a comparative analysis is made of the experience of the two countries as they moved away from their devastating conflicts. ${ }^{1}$ This provides useful information and a means of learning lessons that can inform future policy formation, particularly regarding the roles of the international community and its institutions.

Post-conflict reconstruction involves a number of issues, such as complexities of the preceding conflict, and economic and military security.

The next section briefly considers the problems of postconflict reconstruction in developing countries, illustrating the complexity of the problems facing the survivors and the international community. The following section then compares the experience of Mozambique and Rwanda, giving some brief background to their respective conflicts and some quantitative indicators of their paths of development over the period of reconstruction, before considering the role of the international agencies. Finally some conclusions are presented.

\section{Post-conflict reconstruction in developing countries}

In dealing with post-conflict reconstruction there are a number of important issues that we can categorize as first, implications of the complexity of individual conflicts that complicate policymaking; second, issues of economic security, resulting from the devastation of war; and third, issues of military security, resulting from the difficulties and dangers in ending conflicts.

Complexity of conflicts and the transition to peace

The causes of conflict are as varied as the nature of conflict. The roots of war are multifaceted, with important historical contexts. This has made the first step of conflict resolution a detailed understanding of the background and dynamics of the conflict. Very few conflicts are simple. They seldom have single or even few causes and will often be a combination of many features. ${ }^{2}$ Civil wars are particularly difficult to deal with by military or political means as they often lack a clear military goal. The easy availability of weapons, fragmented polity, alienated young, problems of demobilization, shattered infrastructure, and elites dependent on military rather than civil actions for their power and legitimacy, mean it is little surprise when civil wars restart.

The variety of forms of conflict and the various possible causes of conflict all make peace a difficult achievement. ${ }^{3}$ They also contribute to making recovery from conflict and reconstruction of the country difficult and fraught with the danger of a return to fighting. The peace will first depend on how the war ended, by victory of one side, by international imposition, or by exhaustion, and on whether it does in fact end completely. As war moves to peace the country and economy will require reconstruction and this will certainly need to be designed in such a way as to prevent any of the parties reverting back to war. This of course raises the question of how peace is defined and different groups are likely to disagree on this. Clearly, the process of transition to a commonly accepted "peace" is as important as the end of hostilities. Rehabilitation and reconstruction are likely to aim for more than a return to the pre-conflict economic, political, and social life. This leads to considerable difficulties and specific problems for each individual situation. An important concern is the possibility of moving back to crisis, simply because it makes economic sense. ${ }^{4}$ As Cooper observes post-conflict peace is often no peace at all. ${ }^{5}$

\section{Economic security}

Economic reconstruction is clearly vital and may start before the complete end of the conflict or crisis. An improving economy would clearly make it easier for all stages to be moved through. Whenever it does start, the first actors involved are likely to be the aid agencies and the World Bank and IMF. ${ }^{6}$ The fact that conflict has occurred is likely to mean that a series of changes and promises will be needed to deal with grievances to underpin any peace deal. To ignore these and to impose generic policies for economic growth that may have high short-run costs may well simply lead to a reigniting of hostilities. The protagonists may simply see 
themselves as being better off fighting. There has been considerable debate over the suitability of the policies imposed by the IMF and the World Bank, with organizations such as the ILO questioning the particular path of reconstruction and development put forward by them. ${ }^{7}$

Post-conflict economic and socio-economic problems will of course depend upon the level of development of the country and the damage caused by the conflict. For example, conflict is likely to reduce the capacity of economies to absorb labor, which in turn is likely to lead to reduced employment in the economy. ${ }^{8}$ The end of war does not necessarily imply economic security, and there are risks. First, problems of micro insecurity, with armed inhabitants desensitized to violence, and high rates of robbery, can discourage the acquisition of visible assets. Second, macro insecurity, the considerable risk that war will be resumed. This is particularly important as it can be reflected in political instability, which is likely to discourage private investment, especially foreign direct investment. ${ }^{9} \mathrm{~A}$ third type of risk is the fiscal shocks resulting from the war to peace transition. ${ }^{10}$ It is important for governments to encourage private investors to make investments that are irreversible and this is likely to require the rebuilding of civil society with concern for investment-sensitive reforms, such as control of inflation, proper valuation of the exchange rate, restraint in revenue collection, and the reestablishment of transport infrastructure. Aid can play a vital role in developing the infrastructure and is itself a valuable way of encouraging other investment. Agriculture will be affected through the destruction of other infrastructure, but also has its own problems and given importance of food security is vital to reconstruction. ${ }^{11}$

Military security and demobilization

Conflicts seldom end tidily and continued military action may be required, even if only to defend the peace. Weapons often do not make up the majority of military expenditure in developing economies, and demobilizing soldiers is problematic and can take time. If it is done too quickly, the country could end up with disaffected and armed ex-soldiers, and this can be dangerous. A war economy faced with a sudden change in the form and level of demand will find it difficult to adjust. ${ }^{12}$ After a civil war the first stage may be to "regularize" all ex-combatants and this costs money. It is likely that an exodus to urban areas will be taking place, and it is important to control this to prevent over-saturation and social problems that could lead to further violence. The obvious way to do this is to target the development of rural areas. Failing to prevent the break-up of social groups and communities, which is likely to result from moves to urban areas, could cause conflict with return of ex-combatants who will not be reintegrated into society. ${ }^{13}$ Unfortunately, the fiscal possibilities are also likely to be limited as well, given the state of the economy. Generally, revenue raising improvements will be result of foreign aid and loans and these can cause their own problems. ${ }^{14}$ Aid can destroy the existing market structures and lead to anomalies, such as farmers being ruined by inflows of cheap aid.

While the need for security may lead to armed liberation movements becoming the government, there can be problems with an organization developed for insurrection trying to rule a country in peace, as Lamb describes for Namibia. ${ }^{15}$ It is also possible that continuation of low intensity conflict can be a means of a new elite maintaining control.

All of these concerns suggest that it is important to recognize that developing policies for post-conflict reconstruction is unlikely to be straightforward and will be very much dependent upon the nature, situation, and experience of the individual countries. The next section considers two countries in Africa at different stages of recovery from conflict. It compares their experiences and attempts to draw some lessons.

Comparative assessment

Nature of the conflict

Comparing the experience of Mozambique and Rwanda illustrates the complex nature of conflict well. In Mozambique, independence and the election of FRELIMO led to hostility from the neighboring white minority regimes and the start of a civil war, with the rebel groups supported by South Africa and then-Rhodesia. The achievement of independence had produced initial improvements in the health and education sectors, but there were also economic problems. ${ }^{16}$ The country went bankrupt, and the government almost wholly dependent on foreign aid to pay its workers, while remaining militarized with many adult males knowing only fighting and having little alternative but to resort to robbery and extortion to gain income. ${ }^{17}$ A new liberal constitution and a partial ceasefire in 1990 led to a peace accord in 1992.

Rwanda is a country recovering from a horrific internal conflict. By the end of April 1994, over 1.3 million Rwandans had fled the country, and over 500,000 had been massacred as the result of the civil war and genocide. The ethnic violence was mainly directed by extremists in the majority Hutu ethnic group against the minority Tutsis and moderate Hutus. It was not the first time violence had flared up, but it was the worst. ${ }^{18}$ The invasion of the mainly Tutsi Rwandan Patriotic Front (RPF) from Uganda saw the militia flee and led to a refugee crisis in camps in Zaire (now Congo) and Tanzania. Once the RPF advance on Kigali had been completed, it was agreed to close the camps and let the refugees come back to Rwanda. ${ }^{19}$ 
The Rwanda genocide was clearly not some disorganized outpouring of violence against perceived grievances. It was planned and executed with appalling efficiency, by extremist nationalists within the ruling elite. Yet behind these were important factors that gave rise to the situation. A combination of structural inequality, colonial legacy, economic and agricultural decline, deep-rooted animosity, and the international lack of vision triggered the event of April 1994. The role of the international community both during and after the terrible events is a matter of considerable concern. ${ }^{20}$ The reconstruction of such a scarred and damaged country represented a considerable challenge.

The conflicts in Mozambique and Rwanda differ markedly in a number of ways. The Mozambique conflict, a civil war, which ended in 1992, was an ideological one with a variety of direct foreign involvements. Rwanda had seen earlier ethnic conflict - with massacres of Tutsis since independence and their flight to Uganda (until in the mid-1960s more than half the Tutsi population was living outside Rwanda) - but the genocide of 1994 was unparalleled. The defeat of the Rwandan army by the Rwandan Patriotic Front (RPF) drove the government and many of the perpetrators to Zaire, but conflict continued, with RPF action against the militia in Zaire. Although security concerns were the driving force, later involvement in Zaire-Congo is seen as being driven by the wish to exploit the rich natural resources of its vast neighbor. ${ }^{21}$

The colonial legacy of both countries was important in precipitating the conflict, and poverty and inequality were and are important issues. The Mozambique conflict ended in a peace agreement in 1992, the Rwandan conflict in victory for the RPF. Mozambique has become a democracy, with its first democratic elections in 1994, while Rwanda of necessity introduced a government of national unity, with elections in $2001 .^{22}$

\section{Economic security}

Mozambique and Rwanda have in recent years been among the world's fastest growing economies, although from a low base and with a heavy dependence on aid. Mozambique also suffered devastating floods in 2002. As Figure 1 shows, they did exhibit very different growth paths since the early 1980s, with the Rwandan economy collapsing in terms of per capita GDP over the period of the genocide and conflict from 1992 to 1994. Mozambique, with its more drawn out civil war had a less pronounced decline till the end of the conflict in 1992. The experience of both countries is, however, in stark contrast to the continued growth in per capita GDP for low-income countries as a whole over the period. ${ }^{23}$ Despite their impressive growth rates in the 1990s however, neither country seems to be converging on the average per capita GDP for the world's low-income countries, suggesting continued issues of inequality and poverty, which is a concern.

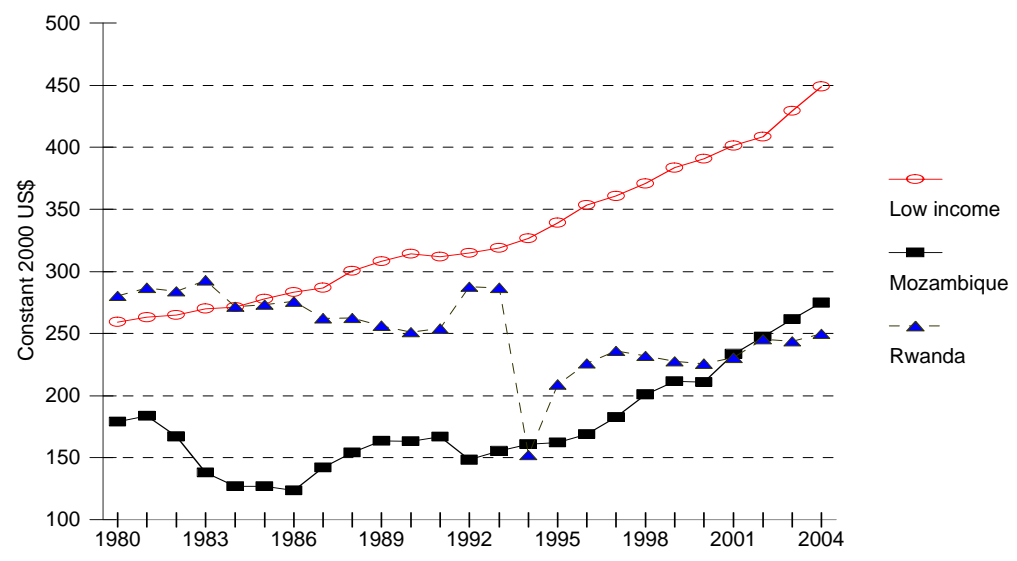

Figure 1: Per capita GDP.

Source: WDI (2006).

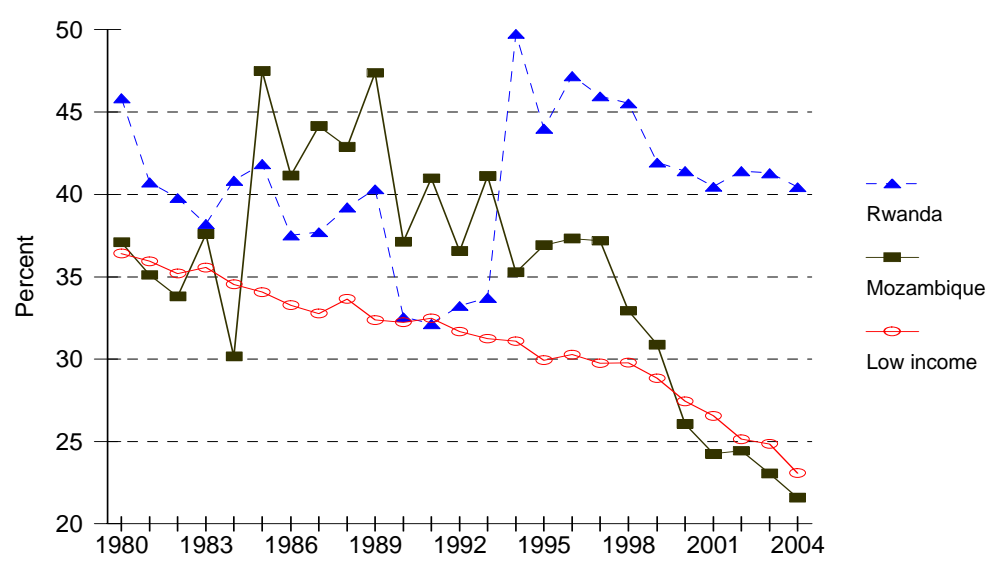

Figure 2: Agricultural value-added as percent of GDP. Source: WDI (2006).

Both countries show a dominance of agriculture in their economies and shares that are high relative to the average for low income countries (Figure 2), but postconflict both have successfully reduced agriculture's share through the development of other sectors of the economy, particularly so for Mozambique.

A useful way of judging the problems faced by people within the country over 


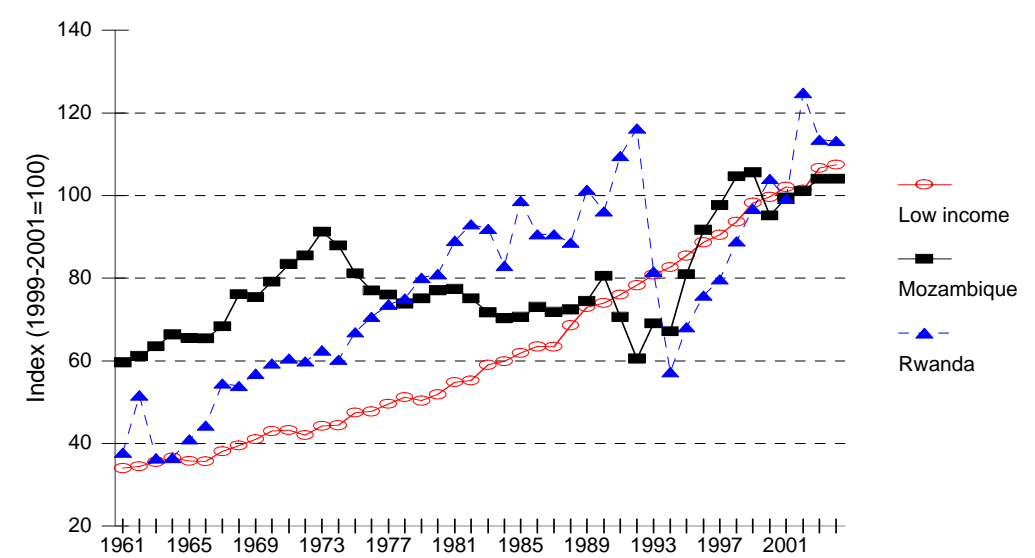

Figure 3: Food production index (1999-2001=100).

Source: WDI (2006).

the period of conflict is to consider food production. As Figure 3 shows, lowincome countries as a whole saw a steady rise in the food production index over the period, whereas the conflict in the two counties made production more erratic, declining from 1990 to 1992 in Mozambique and sharply during 1992-1994 in Rwanda. Given the dependence of these countries on agriculture, these patterns are a clear indicator of the problems and hardships faced by people during the conflicts. They also show the progress that has been made in recent years, particularly in Rwanda.

The response of the international community to the problems is shown in Figure 4, which shows the level of aid received. In both countries, aid grew over the early 1980s and peaked at the height of the conflicts: Mozambique in 1992, and in Rwanda in 1994. The response to the floods in Mozambique in 2002 is clear as well, and both countries still receive high shares of aid relative to the low-income country average.

In analyzing the experience of the two countries, this type of post-conflict quantitative information can only provide a partial picture and one that is ex-post. Qualitative and judgmental indicators are also important, based on the judgements of researchers and agents on the ground. This not only provides important, even if sometimes impressionistic, information, but also allows the validity and reliability of published information to be gauged. Dunne and Mhone report details of studies on Rwanda and Mozambique that collected such information in 2001. This is combined with more up-to-date World Bank statistics in the discussion below. ${ }^{24}$

As we have seen, the international community played an important role in post-

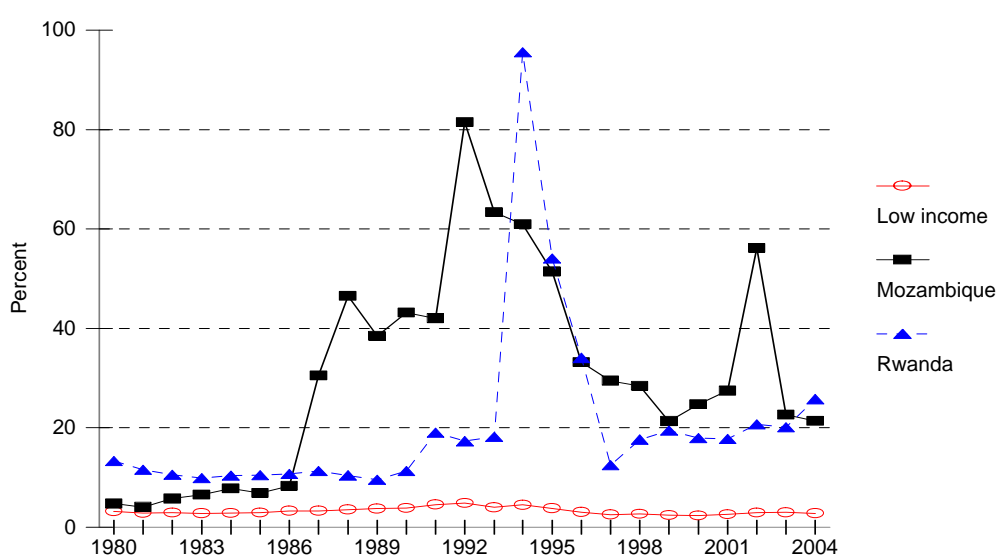

Figure 4: Official development assistance and official aid as share of GNI. Source: WDI (2006).

conflict reconstruction in both countries, but in rather different ways. Not surprisingly, foreign aid became an important part of the two economies in the immediate post-conflict period (Figure 4), but also declined rapidly, particularly in Rwanda. There were also clear differences in the interactions between the two countries and the IMF and World Bank, mainly because of the changes that took place in the attitudes of the institutions. ${ }^{25}$ Mozambique had been involved in the Economic Reconstruction Program from 1986, prior to the end of the conflict, which provided a stamp of approval that made it easier to raise aid and loans, and when the government pressed for rescheduling and relief they gained it in recognition of their attempts to move toward a market-oriented economy. In 1996, the Heavily Indebted Poor Country (HIPC) initiative by the World Bank and IMF provided some relief, contingent on meeting structural adjustment targets, and part of the money was earmarked for debt servicing. Some bilateral lenders have written off debt without conditionalities. This financial assistance came at a cost, however, as the model imposed by the World Bank and IMF was the old structural adjustment one and was inflexible (involving devaluation; elimination of price controls on basic goods; elimination of subsidies on government services; reduced government expenditure and public sector employment; privatization of state assets). The conditionalities attached to the aid caused considerable economic problems and increased poverty levels.

The issue of poverty was a concern in Mozambique well before the World Bank had decided the need for a rethink of its policies in the light of failure and criticism. The old policies had a particularly bad effect on economies disrupted by 
war as evidenced in Mozambique. The supposed trickle-down reduction of poverty was seen as unlikely to impact much on the extreme poverty there and if anything had made matters worse. There were price rises of food as price controls were eased, reductions in food and rent subsidies, reductions in social services, and the introduction of fees for health and education. At the same time, wage increases were not sufficient for many workers to deal with the price increases, and the burden of adjustment fell disproportionately on the poor. Structural adjustment policies also led to large job losses and some suggestions that they were applied in an inappropriate manner. ${ }^{26}$

By 1990, the Mozambique government was pushing for poverty alleviation through the direct allocation of resources to the most vulnerable groups. ${ }^{27}$ From 1990, economic growth averaged six percent per annum, although from a very low base, with inflation virtually eliminated by the late 1990s. Over the period 19941998, the volume of agricultural produce reaching the market more or less doubled. Improvements in transport assisted the peasants in accessing markets but there were still problems in the North and North West regions. Recovery was also constrained by erratic rainfall patterns and the existence of minefields in agricultural areas. A timber boom also took place, particularly for hardwood, although with little attempt at reforestation and hence concerns for sustainability of the resources. Other developments included moves to rehabilitate national parks and to develop tourism, but the ecological problems resulting from overfishing and environmental degradation made these tasks more difficult. The floods in 2002 led to a serious setback in development within southern Mozambique, and the response of international community also showed up some of the tensions between government plans and donor support. ${ }^{28}$ Since then economic growth has moved above trend.

Privatization has not been particularly successful. It led to corruption and confusion, with problems of accountability within the ruling elite, with the problem common in Africa that politics is seen as the most accessible way of accumulating wealth. A number of enterprises fell into financial difficulty, although the inflow of foreign investment in the south of the country - in particular the development of the Maputo transport corridor with South Africa ${ }^{29}$ - did improve the situation. ${ }^{30}$

The experience of Mozambique under the policies of structural adjustment has been mixed, with some promising economic growth at present but clear structural weaknesses and inequality and a concern of unsustainable growth. ${ }^{31}$ As Bruck, et $a l$. ague there are powerful legacies of the war that were not completely understood when the policy was introduced and have shaped the pattern of economic development more than was realized. ${ }^{32}$ It was not the more obvious destruction of capital that came out of the conflict but the less visible damage to institutions, markets and confidence, and the persistence of subsistence agriculture for the majority of the population. They argue that too little attention was paid to the preconditions for the smallholders to develop output, trade, and living standards, and that this has led to an increasing divergence between the rapid urban growth and the slow rural growth that is causing real problems. ${ }^{33}$

Given the economic success of Mozambique in later years, these mistakes represent considerable lost opportunities. They also represented risks to the continuation of peace, but interviews indicated that fortunately there were a number of important programs that attempted to address these problems. These were often introduced and supported by other international organizations, such as the ILO and NGOs: capacity-building activities within the ministries directly aimed at providing necessary skills and technologies, which were particularly important in setting up necessary regulatory system for the private sector; demobilization and integration programs that provided important support for ex-combatants to prevent them moving back to fighting or banditry; labor-intensive road projects, which developed infrastructure in the regions and provided incomes to local people in the regions the roads passed through; and other targeted local development projects that brought employment to the regions were it was needed in an economy dominated by the capital Maputo. All of these, together with the move to democracy, addressed fundamental problems in the continued transition to peace. They did tend to come relatively late in the process, however, in spite of the increased flexibility of the World Bank/IMF policies, and would have been more valuable if they had started earlier, been more extensive, and if the employment intensive techniques had been expanded into other sectors as well. ${ }^{34}$

In its post-conflict reconstruction, Rwanda benefitted from the changed attitudes of the World Bank, and lessons seem to have been learned by international and local advisors from the experience of countries such as Mozambique. That is not to say that mistakes were not made. An initial misguided concern with prioritizing high-tech led growth has been transformed with a clear policy toward recognition of the importance of agriculture and its development. This was particularly important given the small size of the average holdings, the density of population, and the needs for reintegration and is evident in the growth and maintenance of agriculture as a share of GDP (Figure 2) and the impressive growth in food production (Figure 3). The Mozambique experience suggested that it was important to undertake reform and restructuring at the same time and to get to know the nature of the post-war economy. This meant building up capacity in government, both local and national, building up data/knowledge and research on the structure of the post-war economy, improving infrastructure and communication, developing participation, reintegration and entitlement, recognizing the need to improve governance before introducing large-scale privatization and, finally, emphasizing poverty alleviation and the rural economy. All of these were started relatively early in the process of reconstruction in Rwanda, involving international agencies and benefitting from the more flexible 
attitudes of the World Bank/IMF. Another important initiative was the setting up of a Demobilization and Reintegration Commission, with reintegration a particularly important aspect, given the nature of the conflict in Rwanda. Although conflict continued in DRC/Zaire, domestic conflict quickly subsided and successful demobilization became important. Again there were important lessons learned from the experience of countries such as Mozambique in setting up programs. ${ }^{35}$ The more flexible World Bank supported Rwanda's impressive Poverty Reduction Strategy ${ }^{36}$ that was developed, and the benefits are clear from the experience of the economy.

Despite its economic success there are concerns with some of the political and human rights developments in Rwanda. The second Congo war seems to have had little to do with security concerns and more with plunder, and there are concerns that a "commercialized" military can contribute to continued regional instability. ${ }^{37}$ As Guy Lamb (this issue) argues, liberation movements do not necessarily make good governments, and in the case of Namibia exhibited tendencies to autocracy relatively early on. It would be unfortunate if the clear economic successes in the country are undermined by political developments that reignite conflict. ${ }^{38}$

\section{Conclusions}

Comparing the experience of Mozambique and Rwanda as they recovered from crisis is a useful exercise. The most striking difference between the two is the changed role of the World Bank and the IMF in reconstruction. The move away from the failed structural adjustment packages for post-conflict situations to a more flexible policy focused on the Poverty Reduction Strategy, which, while still heavily influenced by the World Bank perspective, meant that Rwanda did not suffer from the classical model of structural adjustment in the immediate period of reconstruction as Mozambique did. More recently, Mozambique has also benefitted from this change in policy, with a willingness by the World Bank to listen to arguments for policies that aim to alleviate poverty, encouragement for domestic ownership of policies, and a more questioned approach to privatization in the absence of governance structures. These changes have also made it easier for international organizations such as the ILO, UNDP, and NGOs to develop programs that focus on the specific problems of post-conflict reconstruction, including demobilization and reintegration, labor-intensive road building, and other local economic development programs. The benefits of these changes are readily apparent from the economic indicators.

That increased flexibility should be important is no surprise, given the complexities and differences identified. It is clearly difficult to make generalizations and design general policies, and it is dangerous to be too formulaic, in the sense of drawing strong policy conclusions from limited information and being inflexible in implementing them. Care is needed, as data are often poor and unreliable, although improving as the country moves through the reconstruction phase. ${ }^{39}$ Having information on what is happening in the country and people on the ground, has enabled the international community to tailor programs for the local areas. It is also be necessary to gauge the less visible legacies of the conflict. The damage on institutions, markets and consumer confidence, the persistence of subsistence agriculture because of lack of support to smallholders, the regional issues, lack of development of living standards, and the divergence of urban-rural development.

It seems that there have been improvements in how the international community has assisted countries moving out of conflict, but this should not lead to complacency. While the comparative analysis undertaken in this article has pointed to important achievements, it has also indicated continuing problems and concerns that urgently need further work.

\section{Notes}

J. Paul Dunne is Professor of Economics at the University of the West of England, Bristol and Chair of EPS(UK). This article is based upon work he undertook for the ILO when he was visiting the Centre for Conflict Resolution and the School of Economics, University of Cape Town. He is grateful for assistance to Guy Lamb and Eugenia Date Bah, Yannick Martin, and all of those who agreed to be interviewed in Rwanda and Mozambique. He is also grateful to Jurgen Brauer, James Markland, Erik Lyby, and Ron Smith for insightful and helpful comments.

1. Dunne (2003); Dunne and Mhone (2003).

2. In each year of the 1980s and 1990s decades there have been between thirty and forty major armed conflicts in progress. The 1996 SIPRI Yearbook lists 30 major armed conflicts in 25 locations in 1995. All were internal or interstate disputes over government or territory. There was a wide variation in the intensity of these conflicts, from "low intensity" guerrilla-government conflicts, to conflicts between relatively large and well-equipped armies. There has also been a prevalence of conflicts within welldefined locational boundaries, often interstate or civil wars. In developed and developing economies the nature of war has undergone important changes, with an increasing role for less formal armies, lack of battlefield engagement, and an increased involvement of civilians as victims (Kaldor, 2001; Duffield, 2001).

3. On the basis of case study analysis of 15 countries, Harris (1999) argues that war is associated with slow growth, declining food production, and declining exports. While war is generally not the only or essential cause of such economic problems, once it has started it does impact negatively on human development.

4. Collier and Hoeffler (2001).

5. Cooper (2006). 
6. An important issue to be dealt with by all those involved is the perceived balancing of the demands for greater economic growth with those for greater social justice and human welfare. This is often externally imposed by the World Bank and the IMF who tend to impose structural adjustment policies for economic growth and to oppose policies that are concerned with social justice and redistribution. Although their attitudes and policies have changed in recent years, this partly reflects past failures and the recognition that they were the result of too rigid an adherence to the doctrine of structural adjustment.

7. These include the concern of the ILO for the reduction of the "decent work deficit" and their arguments for the recognition that different development trajectories can lead to the same outcome in economic terms in the long-run, but the nature of the paths may be very different. See ILO (1995).

\section{ILO (1995); Dunne (2003).}

9. Collier and Gunning (1994).

10. Governments may find it difficult to raise taxes or borrow from the public and will be tempted to print money, possibly resulting in inflation, although a post-Keynesian economist would argue that the link from money supply to inflation is not clear and if anything is likely to be the other way around.

11. It is important to consider both subsistence and commercial farming. The former is crucial as it can allow much of the population to become self-sustaining fairly rapidly, and the latter is important as it may be the only earner of foreign exchange and important in sustaining economic activity in the cities. It is also important to recognize the impact conflict can have on rural household behavior and how this might affect their responses to attempts at reconstruction (Bruck, 2000).

12. In conflict situations, the informal economy can often come to the fore. This can be a complex circuit of exchange with international links, e.g. Sarajevo. But with the end of conflict the strength of this sector can act as a restraint on the reassertion of the formal economy and can introduce criminal elements. Indeed, as Duffield (2002) points out, conflict can lead to a transfer of assets to middle men and this can be extremely destructive and embed inequality. At the same time, this is usually a circulation of goods, with little new production of assets. The informal sector, however, may be the only viable possibility of a livelihood for many and the impact of destroying it through reconstruction policies may not be compensated for by the growth of the formal sector.

\section{ILO (1995).}

14. Such as displacement, dependency, and difficulty in making interest payments.

15. Lamb (in this issue)

16. Hanlon (1996).

17. Harris (2000)

18. Prunier (1995)
19. Dunne (2003). Most of the Government armed forces and their weaponry went to Goma, followed by the RPF. The camps in Tanzania saw less conflict. There are still refugee camps in both countries and concerns over human rights (Reyntjens, 2004).

20. Melvern (2000, 2006).

21. Reyntjens (2004).

22. The elections have come under criticism as being flawed and since then some concerns have been raised over undemocratic actions in Rwanda (Reyntjens, 2004).

23. Separating out the countries growth rates shows Mozambique to have higher growth rates than the average for low-income countries, but with more variance. The conflict led to negative growth in the early 1980s, improving immediately after the imposition of the Economic Rehabilitation Program (ERP) in 1986 to rehabilitate the national economy, but then declining until the 1992 peace agreement and then remaining positive until 2000. In 1989, the ERP became the Economic and Social Rehabilitation Program (ESRP), in an attempt to provide a relief program to the poor and deal with the social crisis created by the ERP. In contrast, Rwanda had low growth rates over the period, sometimes with small negative rates, until after the Arusha accords when the effect of the conflict was catastrophic Dunne (2003).

24. Dunne and Mhone (2003).

25. Stiglitz (2003).

26. The usual example of this is the cashew nut industry, traditionally a major earner of foreign exchange. The World Bank insisted that restrictions on the export of unprocessed nuts be lifted, despite the advice of independent experts. This led to the collapse of the processing industry. The bulk is now exported unprocessed to India. The peasants have benefitted from higher prices offered by exporters, but the job losses in the processing industry have been damaging to the regions affected, particularly in the North (Haines, et al., 2001).

27. Policies include employment generation, the use of labor-intensive production methods, a safety net of transfers, and health and education provision.

28. See Dunne and Mhone (2003) for interview sources for this information.

29. A joint development with South Africa linking Gauteng and Maputo (Haines, et al., 2001).

30. Castel-Branco, et al. (2003).

31. Haines, et al. (2001)

32. Bruck, et al. (2000).

33. Also see Addison (2001a, 2001b) 
34. Such works have been concentrated in the road sector in Mozambique, but this has limited the expansion of the technique into other sectors because of the lack of a "sponsor" at ministerial level (James Markland interview).

35. Dunne and Mhone (2003).

36. Rwanda (2002, 2003)

37. Cuts in military expenditure may have been compensated by more commercial sources of income for the military elite.

38. Reyntjens (2004). Also see Yousif's analysis (this issue) on the United States' post-conflict economic program in Iraq.

39. It is not just the existence of the data that is a concern, but its reliability at any detailed level, given the lack of capability and resources in the countries.

\section{References}

Addison, Tony (ed.) 2003. From Conflict to Recovery in Africa. Oxford: Oxford University Press.

Addison, Tony. 2001a. "From Conflict to Reconstruction.” Discussion paper No. 200/16. World Institute for Development Economics Research (WIDER). Helsinki: United Nations University.

Addison, Tony. 2001b. "Reconstruction from War in Africa." Discussion paper No. 200/18. World Institute for Development Economics Research (WIDER). Helsinki: United Nations University.

Brauer, Jurgen and J. Paul Dunne (eds.) 2002. Arming the South: The Economics of Military Expenditures, Arms Production and Arms Trade in Developing Countries. Houndmills, UK: Palgrave.

Brück, Tilman. 2000. “The Economics of Civil War in Mozambique,” pp. 191-215 in Jurgen Brauer and Keith Hartley (eds.), The Economics of Regional Security: Nato, the Mediterranean and Southern Africa. Amsterdam: Harwood.

Brück, Tilman. 2002. "Ludwig Erhard in Africa: War Finance and Post-War Reconstruction in Germany and Mozambique,” chapter 13 in Jurgen Brauer and J. Paul Dunne (eds.), Arming the South: The Economics of Military Expenditures, Arms Production and Arms Trade in Developing Countries. Houndmills, UK: Palgrave.

Brück, T., E.V.K. FitzGerald, and A. Grigsby. 2000. "Post-War Reconstruction in Nicaragua and Mozambique.” Report to DFID. Oxford: Queen Elizabeth House.

Castel-Branco, Carlos and Christopher Cramer with Degol Hailu. 2003. "Privatization and Economic Strategy in Mozambique," chapter 10 in Tony Addison (ed.), From Conflict to Recovery in Africa. Oxford: Oxford University Press.

Collier, Paul and Anke Hoeffler. 2001. "Greed and Grievance in Civil War.” Revised version of the Policy Research Working Paper No 2355, World Bank.

Collier, Paul and J. Gunning. 1994. "War, Peace and Private Portfolios,” in J.P. Azam et al. Some Economic Consequences of the Transition from Civil War to Peace. Washington, DC: World Bank Research Working Paper 1392, pp. 9-20. http://www.worldbank.org/research/conflict/papers/greedandgrievance.htm

Cooper, Neil. 2006. "Peaceful Warriors and Warring Peacemakers." The Economics of Peace and Security Journal, Vol 1, No. 1. [www.epsjournal.org.uk]

Cooper, Neil. 2002. "The Role of Demilitarization in Promoting Democracy and Prosperity in Africa," chapter 6 in Jurgen Brauer and J. Paul Dunne (eds.), Arming the South: The Economics of Military Expenditures, Arms Production and Arms Trade in Developing Countries. Houndmills, UK:
Palgrave.

Date-Bah, Eugenia (ed.) 2003. Jobs After War. Geneva: International Labor Office.

Duffield, Mark. 2001. Global Governance and the New Wars. London: Zed Books.

Dumas, Lloyd J. 2002. "The Role of Demilitarization in Promoting Democracy and Prosperity in Africa,” chapter 2 in Jurgen Brauer and J. Paul Dunne (eds.), Arming the South: The Economics of Military Expenditures, Arms Production and Arms Trade in Developing Countries. Houndmills, UK: Palgrave.

Dunne, J. Paul. 1996. “"Economic Effects of Military Spending in LDCs: A Survey,” pp. 439-464 in Nils Petter Gleditsch, Adne Cappelen, Olav Bjerkholt, Ron Smith, and J. Paul Dunne (eds.), The Peace Dividend. Amsterdam: North-Holland.

Dunne, J. Paul and Guy Mhone. 2003. Africa's Crises: Recent Analysis of Armed Conflicts and Natural Disasters in Africa. In Focus Programme on Crisis Response and Reconstruction Working Paper No. 5. Recovery and Reconstruction Department. Geneva: International Labor Office. http://www.ilo.org/public/english/employment/recon/crisis/download/wp5.pdf

Dunne, J. Paul. 2003. "Armed Conflicts, Decent Work and Other Socio-economic Issues in Africa," chapter 2 in Eugenia Date-Bah (ed.), Jobs After War. Geneva: International Labor Office.

EIU. 2001. “Country Report: Rwanda, Burundi.” London: The Economist Intelligence Unit.

Gourevitch, Philip. 2000. We Wish to Inform You that Tomorrow We will be Killed with Our Families. Picador: Basingstoke and Oxford.

Haines, Richard, David Noon, and Geoffrey Wood. 2001. "Structural Adjustment in Mozambique: Consequences and Options.” Paper presented to the South African Sociological Association. Annual Congress. Pretoria: University of South Africa.

Hanlon J. 1996. Peace Without Profit: How the IMF Blocks Rebuilding in Mozambique. Oxford: James Currey.

Harris, Geoff (ed.) 1999. Recovery from Armed Conflict in Developing Countries: An Economic and Political Analysis. London: Routledge.

[ILO] International Labor Office. 1995. "Reliance and Potential of Employment-Intensive Work Programmes in the Reintegration of Demobilized Combatants.” Development Policies Branch. Geneva: International Labor Office.

Kaldor, Mary. 2001. New and Old Wars. London: Polity Press.

Keane, Fergal. 1996. Season of Blood: A Rwandan Journey. London: Penguin Books.

Lamb, Guy. 2006. “Militarization’s Long Shadow: Namibia’s Legacy of Armed Violence.” The Economics of Peace and Security Journal. Vol. 1, No. 2 (this issue). [www.epsjournal.org.uk]

Marshall, K. 1998. "From War and Resettlement to Peace Development: Some Lessons from Mozambique and UNHCR and World Bank Collaboration.” Boston, MA: Harvard Institute for International Development.

Melvern, Linda R. 2006. Conspiracy to Murder: The Rwandan Genocide. London: Verso.

Melvern, Linda R. 2000. A People Betrayed: The Role of the West in Rwanda's Genocide. London: Zed Books.

Prunier, G. 1995. The Rwanda Crisis: History of a Genocide. London: Hurst \& Company.

Reyntjens, Filip. 2004. "Rwanda 10 Years on: From Genocide to Dictatorship.” African Affairs, No. 103, pp. $177-210$

Rwanda. 2001. "Rwanda Development Indicators, 1999.” Department of Statistics. Ministry of Finance and Economic Planning. Kigali: Rwanda.

Rwanda. 2002. "The Poverty Reduction Strategy.” Ministry of Finance and Economic Planning. Kigali: Rwanda.

Rwanda. 2003. "Poverty Reduction Strategy - Progress Report.” Ministry of Finance and Economic Planning. Kigali: Rwanda.

Stiglitz, Joseph. 2003. Globalisation and its Discontents. London: Penguin Books.

[UNDP] United Nations Development Program. 1998. "Report on the Reintegration of Demobilized Soldiers in Mozambique, 1992-96.” Maputo: UNDP. 